\title{
An exploration study to find important factors influencing on brand in rubber industry
}

\author{
Mehrnaz Moshkelati", Elham Eghbali, Hamed Asgari and Hamid Bagheri
}

Department of Management, Islamic Azad University, South Tehran Branch, Tehran, Iran

\begin{tabular}{l}
\hline C H R O N I C L E \\
\hline Article history: \\
Received May 12, 2013 \\
Received in revised format \\
25 June 2013 \\
Accepted 27 June 2013 \\
Available online \\
July 2 2013 \\
\hline Keywords: \\
Rubber industry \\
Factor analysis \\
Brand image
\end{tabular}

\section{Introduction}

Brand plays an important role for the success on any industry including rubber industry. There is a high competition in rubber industry since profit margin in this industry is not significant and only efficient and well known firms could survive (Stigler, 1961; Stiglitz \& Weiss 1981; Franco, 1990). Therefore, there is a need to investigate brand characteristics and find out how to build a good one. Erdem and Swait $(1998,2004)$ investigated the effect of brand credibility, trustworthiness and expertise, on brand choice and consideration across multiple product categories, which may vary in regard to potential uncertainty about attributes and associated information acquisition expenses and perceived risks of consumption. They reported that brand credibility increases probability of inclusion of a brand in the consideration set, as well as brand choice conditional on consideration. In addition, although credibility influences brand choice and consideration set formation more and through more constructs in contexts with high uncertainty and sensitivity to such uncertainty, credibility effects are

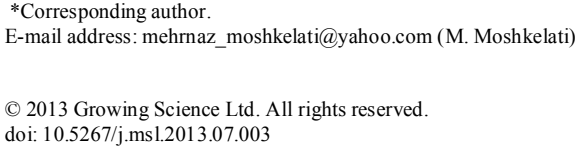


present in all different categories. They concluded that trustworthiness influences consumer choices and brand consideration more.

Brands can influence different stages of consumer choice processes, and hence, different components of consumer utility functions. Previous conceptual and empirical work concentrated on the impacts of brands on consumer perceptions of tangible and intangible product attributes. Erdem et al. (2002) extended the work on brand effects with information economics underpinnings to investigate whether consumer price sensitivity, that is, the weight attached to price in a consumer valuation of a product's or nor brand credibility could influence overall attractiveness or utility. They studied how the effect of product price on consumer utility was moderated by brand credibility. To explore the effect of brand credibility on consumer price sensitivity across categories that may involve various levels of consumer uncertainty, they performed the analysis for four products including frozen concentrate juice, jeans, shampoo and personal computers. These categories differed in the degree of potential consumer uncertainty about product attributes, as well as in a number of other category-specific features, which may influence consumer sensitivity to uncertainty. Their results disclosed that brand credibility could decrease price sensitivity and although the direction of the effect was the same, the magnitude of brand credibility's effect on consumer choices and price sensitivity could be different across product categories, as a function of product category characteristics, which influence potential consumer uncertainty and consumer sensitivity to such uncertainty.

Sweeney and Swait (2008) investigated the important additional effect of the brand in managing the churn of current customers of relational services. They proposed that the credibility of the brand could underlay the effect that the brand could play in this process. In their survey, brand had a significant role on managing long-term customer relationships, and detailed how the usual tools of customer relationship management, satisfaction and service quality were associated with brand credibility.

Berry (2000) presented a service-branding model, which underscores the salient effect of customers' service experiences in brand formation. Four primary strategies that excellent service firms implement to cultivate brand equity were discussed and illustrated. They stated branding is not just for tangible goods and it is a principal success driver for service organizations as well. Gilliland, and Bello (2002) investigated on two sides to attitudinal commitment including the effect of calculative and loyalty commitment on enforcement mechanisms in distribution channels.

Wray et al. (1994) presented a neural network with two outcome components of relationship quality, relationship satisfaction and trust, and five input antecedents including the salesperson's sales orientation, customer orientation, expertise, ethics and the relationship's duration. The work contributed towards the development of the technique and provided a number of further possible applications. Harris and Goode (2004) performed a study of online service dynamics on four levels of loyalty and the pivotal role of trust. They stated that the hypothesized cognitive-affective-conativeaction loyalty sequence was statistically most likely out of all possible variations. Their structural modeling supported the hypothesized framework and positions trust as central to service dynamics.

\section{The proposed study}

This paper presents an empirical investigation to find important factors influencing rubber industry. The proposed study designs a questionnaire in Likert scale consists of 20 questions, distributes it among 300 people and collects 265 filled ones. Cronbach alpha is calculated as 0.756 . In addition, Kaiser-Meyer-Olkin Measure of Sampling Adequacy and Approx. Chi-Square are 0.75 and 1292.573, respectively. Since we plan to factor analysis and this method is sensitive to skewness of the data we first look at some of the basic statistics including the skewness of the data, which are summarized in Table 1. 
Table 1

The summary of basic descriptive statistics

\begin{tabular}{|c|c|c|c|c|c|c|c|c|c|}
\hline & \multirow{2}{*}{$\begin{array}{c}\mathrm{N} \\
\text { Statistic }\end{array}$} & \multirow{2}{*}{$\begin{array}{l}\text { Range } \\
\text { Statistic }\end{array}$} & \multirow{2}{*}{$\begin{array}{c}\text { Minimum } \\
\text { Statistic }\end{array}$} & \multirow{2}{*}{$\begin{array}{c}\text { Maximum } \\
\text { Statistic }\end{array}$} & \multirow{2}{*}{$\begin{array}{l}\text { Std. Deviation } \\
\text { Statistic }\end{array}$} & \multicolumn{2}{|c|}{ Skewness } & \multicolumn{2}{|c|}{ Kurtosis } \\
\hline & & & & & & Statistic & Std. Error & Statistic & Std. Error \\
\hline Q1 & 285 & 4 & 1 & 5 & 1.093 & -1.007 & .144 & .345 & .288 \\
\hline Q2 & 285 & 4 & 1 & 5 & .928 & -.762 & .144 & .309 & 288 \\
\hline Q3 & 285 & 4 & 1 & 5 & .983 & -.515 & .144 & -.332 & .288 \\
\hline Q4 & 285 & 4 & 1 & 5 & 1.135 & -.516 & .144 & -.518 & 288 \\
\hline Q5 & 285 & 4 & 1 & 5 & .980 & -.646 & .144 & -.064 & 288 \\
\hline Q6 & 285 & 4 & 1 & 5 & .984 & -.425 & .144 & -.434 & 288 \\
\hline Q7 & 285 & 4 & 1 & 5 & 1.138 & -.301 & .144 & -.707 & .288 \\
\hline Q8 & 285 & 4 & 1 & 5 & 1.221 & -.262 & .144 & -1.002 & .288 \\
\hline Q9 & 285 & 4 & 1 & 5 & 1.090 & -.338 & .144 & -.716 & .288 \\
\hline Q10 & 285 & 4 & 1 & 5 & 1.060 & -.368 & .144 & -.518 & .288 \\
\hline Q11 & 285 & 4 & 1 & 5 & 1.124 & -.416 & .144 & -.614 & .288 \\
\hline Q12 & 285 & 4 & 1 & 5 & 1.058 & -.428 & .144 & -.451 & .288 \\
\hline Q13 & 285 & 4 & 1 & 5 & 1.027 & -.591 & 144 & -.287 & .288 \\
\hline Q14 & 285 & 4 & 1 & 5 & 1.200 & -.248 & .144 & -.855 & .288 \\
\hline Q15 & 285 & 4 & 1 & 5 & 1.103 & -.330 & .144 & -.618 & .288 \\
\hline Q16 & 285 & 4 & 1 & 5 & .919 & -.351 & .144 & -.295 & .288 \\
\hline Q17 & 285 & 4 & 1 & 5 & .985 & -.156 & .144 & -.446 & .288 \\
\hline Q18 & 285 & 4 & 1 & 5 & 1.051 & -.200 & .144 & -.632 & .288 \\
\hline Q19 & 285 & 4 & 1 & 5 & 1.022 & -.148 & .144 & -.617 & .288 \\
\hline Q20 & 285 & 4 & 1 & 5 & .953 & -.369 & 144 & -.201 & .288 \\
\hline Valid N (listwise) & 285 & & & & & & & & \\
\hline
\end{tabular}

As we can observe, we need to remove the first question due to skewness issue and the rest of the survey has been accomplished based on the remaining 19 questions. Table 2 demonstrates the results of factor analysis on these factors.

Table 2

The summary of factor analysis

\begin{tabular}{|c|c|c|c|c|c|}
\hline Factor & Measurable variable & Weight & Eigenvalue & Variance & Accumulated \\
\hline \multirow{5}{*}{ Brand transparency } & Reliability of product delivery & 0.728 & 2.55 & 13.42 & 13.42 \\
\hline & Honesty & 0.72 & & & \\
\hline & Security & 0.617 & & & \\
\hline & Communication & 0.608 & & & \\
\hline & Reliability of employee & 0.569 & & & \\
\hline \multirow{4}{*}{ Expected quality } & High quality brand & 0.836 & 2.351 & 12.372 & 25.792 \\
\hline & High level of consistency & 0.768 & & & \\
\hline & Expected characteristics & 0.574 & & & \\
\hline & Reliability of brand & 0.537 & & & \\
\hline \multirow{3}{*}{ Brand promises } & Health Brands & 0.769 & 1.804 & 9.497 & 35.289 \\
\hline & promises & 0.597 & & & \\
\hline & Competencies & 0.567 & & & \\
\hline \multirow[t]{2}{*}{ Trust } & Reputation & 0.71 & 1.697 & 8.933 & 44.223 \\
\hline & Honesty & 0.603 & & & \\
\hline \multirow{3}{*}{ Support } & Support & 0.76 & 1.655 & 8.709 & 52.932 \\
\hline & Commitment & 0.559 & & & \\
\hline & Increase in trade transactions & 0.507 & & & \\
\hline \multirow[t]{2}{*}{ Sustainability } & Continuity & 0.767 & 1.641 & 8.635 & 61.567 \\
\hline & Brand loyalty & 0.755 & & & \\
\hline
\end{tabular}




\section{Discussion and conclusion}

The results of Table 2 indicate there are six important factors influencing brand in rubber industry including, transparency, quality, promises, trust, support and sustainability. In terms of transparency, reliability of the delivered products is number one priority followed by customers' honesty, security and communication. Quality is the second factor consists of five sub-components including high quality brand, high level of consistency between what they offer, expected characteristics and reliability. The third factor, brand promises, consists of three factors including health of brands, different promises and competencies. Trust is the fourth factor, which includes two sub-components of reputation and honesty. Technical support is the fifth factor with three sub-component including support, commitment and increase in trade transactions. Finally, sustainability is the last item, which includes continuity and loyalty.

\section{Acknowledgment}

The authors would like to thank the anonymous referees for their construction comments on earlier version of this work.

\section{References}

Berry, L. L. (2000). Cultivating service brand equity. Journal of the Academy of Marketing Science, 28(1), 128-137.

Erdem, T., \& Swait, J. (1998). Brand equity as a signaling phenomenon. Journal of consumer Psychology, 7(2), 131-157.

Erdem, T., Swait, J., \& Louviere, J. (2002). The impact of brand credibility on consumer price sensitivity. International Journal of Research in Marketing,19(1), 1-19.

Erdem, T., \& Swait, J. (2004). Brand credibility, brand consideration, and choice. Journal of Consumer Research, 31(1), 191-198.

Franco, J. J. (1990). Customer satisfaction: The partnership imperative. Training and Development Journal, 44(7), 80-82.

Gilliland, D. I., \& Bello, D. C. (2002). Two sides to attitudinal commitment: the effect of calculative and loyalty commitment on enforcement mechanisms in distribution channels. Journal of the Academy of Marketing Science, 30(1), 24-43.

Harris, L. C., \& Goode, M. M. (2004). The four levels of loyalty and the pivotal role of trust: a study of online service dynamics. Journal of retailing, 80(2), 139-158.

Stigler, G. J. (1961). The economics of information. The journal of political economy, 69(3), 213225.

Stiglitz, J. E., \& Weiss, A. (1981). Credit rationing in markets with imperfect information. The American economic review, 71(3), 393-410.

Sweeney, J., \& Swait, J. (2008). The effects of brand credibility on customer loyalty. Journal of Retailing and Consumer Services, 15(3), 179-193.

Wray, B., Palmer, A., \& Bejou, D. (1994). Using neural network analysis to evaluate buyer-seller relationships. European Journal of Marketing, 28(10), 32-48. 